\title{
A Critical Reflection on the Rights and Exploitation of Non-Humans in Omo-river Valley (Gibe-III) Areas
}

\author{
Daniel Techan, Bisrat Tesfay \\ Department of Civics \& Ethical Education, Wolaita Sodo University, Wolaita Sodo, Ethiopia \\ Email address: \\ Techan.danie19@gmail.com(D. Techan),btdesalegn@gmail.com (B. Tesfay)

\section{To cite this article:} \\ Daniel Techan, Bisrat Tesfay. A Critical Reflection on the Rights and Exploitation of Non-Humans in Omo-river Valley (Gibe-III) Areas. \\ Humanities and Social Sciences. Vol. 8, No. 3, 2020, pp. 92-99. doi: 10.11648/j.hss.20200803.12
}

Received: May 11, 2020; Accepted: June 1, 2020; Published: June 29, 2020

\begin{abstract}
The paper explores the critical reflection of the exploitation of the natural environment, specifically forest in Omo-river valley areas. Forests and trees have been destructed and cut down of trees, for charcoal business to fulfill their personal financial/economic interest. The researchers also disclosed the multiple impacts of the cut down of trees and forests for charcoal trade. Hence, the researchers attempts to critically understand and analyze such over exploitation of land and natural environment. In this paper, the researchers explained the genuine causes of the charcoal production beyond the immediate benefit they could get. Accordingly, the researchers found both the anthropocentric and divine approaches of environment problematic and factors for the exploitation of the natural environment. In this paper, the central emphasis is the unwise utilization of the environment for different purpose (which we can call it violation of rights of the non-human creatures from the view point of the biocentrism perspective; the diversified species who live in the area and the destruction of the forest coverage for the sake of temporary economic gain) Generally, to solve the problem the researchers came up with Aldo Leopold's new environmental argument of the "land ethic" and other apparatuses of environmental conversation. With this regard Leopold's argument of "land ethic" argued that, our approach towards the land, and natural environment should be those are the environment friendly strategies and holistic reforms to be taken by the government and specifically optional energy sources for the society.
\end{abstract}

Keywords: Charcoal Trade, Non-human, Exploitation, Anthropocentric, Bio-diversity

\section{Introduction}

River basin development in Africa has nearly unparalleled significance for the future on entire nations. Most major hydro- dam projects undertaken in Africa have produced intense controversy, particularly over their socioeconomic and environmental impacts [1]. However, the central concern of the paper is not emphasizing the impact of the dam towards natural environment, but it appeals to the destruction of trees and forests for private and business utility near to the dam (gibe III). The major aspect of this paper is to look into the right violation of non-human in the study area following the charcoal business and to reflect the possible environmental ethics for utilization of the environment for different purpose.

The study area is located about $62 \mathrm{~km}$ west of Wolayta Sodo in the Southern Nations, Nationalities, and Peoples' Region. It is the fifth largest hydroelectric plant in Africa with a power output of about 1870 Megawatt (MW), (thus more than doubling total installed capacity in Ethiopia from its 2007 level of $814 \mathrm{MW}$ ). The Dam is located in between Wolaita zone and Dawro zones. The Gibe III dam is part of the Gibe cascade, a series of dams including the existing Gibe I dam (184 MW) and Gibe II power station (420 MW) as well as the planned Gibe IV (1472 MW) and Gibe V (560 MW) dams.

Gibe III, the tallest roller-compacted concrete (RCC) dam in the world, with $246 \mathrm{~m}$ dam height and $630 \mathrm{~m}$ crest length, was inaugurated in December 2016. The USD 1.8 billion construction was financed 40 per cent by the Ethiopian Government, and 60 per cent by the China Exim Bank, International hydropower association, 2017 [2].

The topography, aesthetic values of the area and above all the habitability for different species is the major manifestation of the area. It is obvious that every country strongly seek materializing development and development is 
not all about wishes; that is why country adopt/follow different development policies and strategies. Though, there exist a lot of compulsory components of development energy is among the fundamental. Hydropower plants are the best environmental friendly sources of energy compared to oil and charcoal. Despite this advantage, following hydropower plants it may result in the destruction and exploitation of the environment and its surrounding. This implies that there are "various human factors drive, influence and affect environmental change at the global, regional, national and local levels" [3]. For instance, when we see the case of the Gibe III areas, wild community lives, particularly trees have been also chopping for charcoal business.

We will instigate our discussion by emphasizing the exploitations and devastations of non-human environmental resources for charcoal trade in Omo-River Areas. Second, we will describe the impacts of the exploitation and devastation of non-humans (trees, forests and grasses). Thirdly, we will identify and discuss some of the fundamental Causes of the Exploitation of Non-Humans. In the last, we will appeal to the conservation arguments of natural environment and we will point out important points to protect and respect the nonhuman (wild lives).

\section{Exploitation and Devastations of Non-Human in Omo-River Areas}

In most part of Ethiopia, the non-humans resources such as trees, plants, and animal are subject to destruction, exploitation, and pollution. And omo-river area is not exceptional from such kind of destruction of non-humans. Omo-river area is endowed with the diversity of plants, trees, wildlife, and other species of birds and it is also covered by forests and grasses. However, the people have been chopping down and destroying forests for energy consumption and for charcoal trading.

Charcoal is a black carbon that made from the burned wood. It is the main source of income for some members of the society. The society have been degrading and burning the wide areas covered by forest and grass to produce charcoal carbon for sale and private consumption. Large trees and grasses have damaged by the fire. When the individuals cut down trees to produce charcoal, they failed to rehabilitate the area. Due to this, the area is now at high risk of deforestation and is bare. Accordingly, the researchers are impressed to concern with the issue explained above because it leads to [4] other multitude impacts. In accordance with, Jamieson said, environmental problems are diverse in scale, impact, and the harms they threaten. They can be local, regional, or global, they can involve setbacks to human interests, or they can damage other creatures, species, or natural systems [5].

It is clear that there are various common factors for the destruction and exploitations of natural environment, such as, war, agriculture, bio-degradability, grazing, deforestation, erosion and climate change. Like humans, other non-humans such as, plants and animals, even other natural resources need care and conservation by the people. But in Ethiopia it is different from that; animals and plants seems they are created as servants of human beings. Exploiting, devastating, killing, hurting animals, cutting plants without replacing is common. Societies in Ethiopia do not have the culture of caring of physical environments. They missed that the physical world, plant, animal, even mountains are part of us and people have the obligation to conserve them all. This destruction, devastation and/or pollutions of natural resource are mainly caused by the following core points:

People who live surrounding of Omo-river have been devastating the natural resource for temporal consumption. The researchers critically disclosed the destruction and damage of natural environment of the society for short period personal consumption. However, this destruction of natural environment for spatiotemporal use necessarily causes serious environmental problem of the future. It would be a cause for economic, social, natural, and cultural problems with in the society and outside or global. Even though there are different types of environmental exploitations and destructions practiced by the society, but the researchers are impressed with one that is commercial charcoal carbon production to satisfy their personal interest.

The study also focused on the rights of the environment and duties of the people towards the non-humans including the environment itself. The rights of animals are very controversial and debatable. The duty of individuals is not merely refraining themselves from harming and exploiting the natural environment, but also they have the obligation to conserve or preserve them.

\section{The Diverse Potential Impacts of Charcoal Production on Human and Non-Humans}

Indeed there are different reasons for the involvements of youths in charcoal trade, such as unemployment, economic/financial deficit and others. Basically cutting down of trees has a significant role in degrading soils and destruction of forests. But beyond that it is better to understand the diverse impacts of the charcoal business to the humans and non-humans in general. This may cause ecological transformation such as: soil degradation/damage, destruction of species, air pollution, rainfall diminishing, and wildlife demolition.

\subsection{Deforestation and Soil Degradation}

It is obvious that soil is one of the most important resources for life and existence of other living things. It is a critical to the world, supplying virtually all the food and fiber that sustain the human population and providing ecosystem services that support life [6]. This shows the necessity of soil for trees and wildlife. But by many things, like natural and artificial disasters the soil can be degraded and destroyed. And, charcoal business is one of the factors of soil degradation because this is happens due to the chopping of 
trees and forests and this lead to clearing of forest. Deforestation has negative impact on the sustainability of biodiversity, climate and water resources. Therefore, conserving the trees and forest has very much important than deforesting and clearing trees, According to Dowie, When, after setting aside a 'protected' land mass the size of Africa, global biodiversity continues to decline and the rate of species extinction approaches one-thousand times background levels, the message seems clear that Deforestation Around the World there might be something terribly wrong with this plan... A better strategy might be simply to turn more human beings into true conservationists [7].

\subsection{Global Warming/Climate Change}

Global warming is the ultimate impacts of chopping down of trees and forests for charcoal trade and the world at high frustration of global warming. With this regard atmospheric scientists tell us that "we have set in motion events that will take more than a century to play out, and that the result is almost certain to be a climate that is warmer than humans have ever experienced".

Forests and trees play a tremendous role in normalizing the global climate change since they produce oxygen. When the forests and trees are chopped down for charcoal trade, it has double impacts with this context on the environment; the first one is, the immediate carbon which comes from the fire pollutes the environment and the second one is, there would no oxygen which potentially generated from the forest. These two impacts of destruction of trees and forests for charcoal trade plays a vital role in global warming and/or climate change. The climate change that is now under way is largely caused by the emission of carbon dioxide (Ibid).

Thus, charcoal trade is one of the factors of air pollution and it has a significant role in global warming accordingly. However, individuals who live in that area are least responsible for the climate change and the exploitation of the environment. They only concern on how they could use of natural environments for short term.

\subsection{Rain Fall Waning}

Most of the time, the amount of rainfall in a specific place is determined by the appearance of forests, trees and grasses coverage. If certain area is dry, the rainfall will be low, on the other hand, when certain place is covered by dense forest necessarily, it would have high amount of rainfall in that place. Therefore, forests and trees are important in increasing rainfall. But trees and forests have been chopping down widely in Omo-river areas for charcoal trade and it will have a substantial impact in rainfall diminishing and depletion.

\subsection{Migratory of Species}

Animals/wildlife parking has a significant role for the source of income in tourism department.

There are various factors for migration of the species of wild life. Among the major factor for the migration of wildlife is chopping and firing of forests, trees. Individuals live in omo-river areas chop down and fire tress for the charcoal business. When they cut down the trees and fires forest different animal species who have been living in the area forced to migrate to other places to save their life.

\subsection{Aesthetical Disaster}

Aesthetics can be defined as "a branch of philosophy which concerned with beauty and art" [8]. In the contemporary world, the word refers to 'the apparent embodiment of emotion in art', or the New English Dictionary's 'philosophy or theory of taste or the perception of the beautiful in nature and art', [9].

Here, in this paper, it depicts specifically to the ecological and environmental beauty. The ecological and environmental beauty is necessarily actualized by protecting, caring, conserving all creatures, mainly the forests, and trees (because they are home to a variety of animals and birds).

Natural environments aesthetic value will persist as far as each and every one have its roles of preserving them. Omoriver valley area is naturally attractive and has a strategic potential for tourism sites. The area has tremendous view looking from the edge of the mountain. However, the area is in danger of the chopping and cutting down of trees and forests for charcoal trade. The deforesting of the area for charcoal trade is the other critical impact of the aesthetical disaster of the area. Thus, charcoaling has to be stopped for the matter of the aesthetic value of the area. Jamieson argued., "These days the aesthetic qualities of nature are commonly invoked to justify preservation of nature areas".

\section{Some Core Causes of the Exploitation of Non-Humans}

There are different causes for the exploitation of nonhumans and/or natural environment. One and the immediate cause of the devastation of natural environment observed by the researchers in the study area is the charcoal business. Individuals have been chopping trees, burning grasses need for charcoal production for sale. As Anderson said, this may be occurred because of "poverty, joblessness, and inequitable land distribution, which force many landless peasants to invade the forest for lack of other economic means, continue to drive forest clearance for subsistence farming in many regions" [10]. The overall poverty of the country and following this, lack of fundamental social facilities, like electricity or any alternative energy, and joblessness are the core causes for the individuals who are involved in charcoal business. But the scope of the paper is not limited to the rights of the non-humans but also, the burdens that humans face due to the destruction of forests and trees.

Thus, the researchers disclosed the two perspectives as core causes for the destruction of the natural environment due to charcoal business. 


\subsection{Anthropocentrism and Divine Perspectives}

Indeed there are various environmental perspectives but in this paper the main emphasis goes to the objection of the two major approaches in environmental ethics; anthropocentrism and the divine. The researchers believe that these perspectives have negative impact on the non-human creatures. The purpose of this paper, in this regard, is to find alternative environmental model with minimum impact on the non-human creatures for the reason that both anthropocentric and divine environmental perspectives could be the causes for the exploitation of non-humans in omoriver areas.

Anthropocentrism

The natural world is in a chronic state of crisis and under constant threat of degradation, primarily by anthropogenic factors [11]. According to Slootweg, "the main threats to global biodiversity/natural environment are associated with human activities". Anthropocentrism is an environmental perspective which argues that "all and only human beings have inherent worth. All other things- including the environment - are only valuable because we value them (subjective value) or because they are useful for accomplishing our goals or promoting our well-being (instrumental value)" [12]. This theory seems egoistic because it outlooks we should have only value environment and non-humans since they are useful for us. This theory argues that non-humans do not deserve respect, unless they give a significant contribution to human being. However, such kind of argument is with profound impacts on both the non-human and human creature itself. Instead, the association between wild community life and human should be with due respect (i.e. as human being have an intrinsic value, other creatures should also entitle that value).

The anthropocentric theory does not give a credit for the right of the non-humans to exist and individual's duty to protect and care them from harmful deeds. This imagination is one of the factors for the chopping down of forests and trees for charcoal trade by those of who live in omo-river area. In this regard the researchers argue that the exploitation of non-humans mainly the cutting down of trees for private and short period usage has a long lasting and disastrous outcome, like global warming, rainfall dimensioning, destruction and immigration of wild life and destruction of the landscape and aesthetical beauty of the area.

Accordingly, the argument of the anthropocentrism is highly problematic for the non-humans. The problem of the argument is with the idea that only human beings have essential value and the value of natural environment or the non-humans is determined by human beings. This view interpreted as either the value of non-humans/natural environments without human beings is meaningless or the value of non-humans without human being does not exist.

Herewith, we strongly criticize the anthropocentric argument of human centrism. First we have to acknowledge their existence and if we assure their existence we have to work for their safety as we do for ourselves. As human being we are thinking animals and we have to quest like what is the end of the existence of non-humans in the world? Are they living for the wellbeing of human beings and with what kind of rights or respect? If so, how do we know?

These questions have to be considered, for any human kind to advocate the theory of anthropocentrism. Therefore, we reject the anthropocentric theory, since it failed to answer the above critical questions. We reject this theory by considering the following points; thinking loud about the future generation, the rights of the others not involved in, replacing or replanting and others are the core points.

The other environmental theory which is problematic is the divine theory.

\subsection{Natural/Divine Perspective}

The divine perspective is somehow concerned with the ideology of Christianity towards natural environment including wildlife and plants. According to Christianity, all non-humans are created by the God for the wellbeing of human being because human being is the dominant among the creatures of God. With this regard Theroux argued,

A strong set of arguments states that human beings are the highest form of natural creation and, therefore, should have complete dominion over nature and everything that it contains. Nature exists strictly for the use of human beings and has no other purpose for its existence. These arguments come from two sources: religion and science [13].

According to this quotation, everything existed in the universe or world is created for the affluence of human being. There is no genuine objective of non-human creatures other than serving humans. Herewith, we need to appeal to the golden rule of the classical instance of normative principle. The principle of golden rule implies that "we should not do to others what we would not want others to do to us." What we should have taken in to our account from this statement is that, the principle should also consider human and nonhuman (animals and plants) relationship.

And we believe that we should not do to animals and plants that what we would not want others to do for us. For the reason that, we have to think out loud that there is no plant and animal that would be comfortable to be harmed, killed, and chopped by human beings. For example, when we chop some or essential parts of trees and plants gradually, it led them to suffer and finally they may die. Likewise, as we need to catch and hunt animals for food and other related use, most of the time they are conscious of that they would be in danger and then they would take action that may be either running to escape from the expected harm or defending themselves to save their life from hazard. Therefore, what we can understand from this that animals are a bit conscious about their life.

Accordingly, as we are human being and rational animals we have to sense the pain of trees, plants and other wildlife and significantly conserve them. However, this kind of treatment and preservation of non-human is too much strange to the community and it is national wide. For instance, donkey is one of the most burdened animals in most parts of 
Ethiopia. Majority of the society in Ethiopia does not respect and treat donkey likewise of the respect and good treatment given to other animals. Moreover, the societies believe the task of donkey isn't limited to weight transportation but also it is created to be kicked and harmed hardly. This kind of assumption is primarily associated to the divine perspective; the non-humans are created to give service for humans.

The peoples approach towards non-humans is determined by the benefits they could obtain from them. That may be the necessary reason that made the people has a negative association towards the donkey and other wildlife. What we can understand from this is human beings are selfish and usually act and pursue for their own satisfaction as the expense of non-humans.

In this regard, such questions can be raised; "how do we know whether these things are really created to serve us"?

The study area plays a tremendous role in generating hydro-electric power to the country electric consumption and for export. The river is surrounded by mountains covered by diversified plants and trees. However, the forests, trees are cut down for wood and charcoal production for personal use and for sale. The people who live surrounding Omo River use this charcoal production as source of income. For this reason the forests are disappearing and wild animals which live in the forest are endangered.

This wide cut down and disappearing of trees and forests without replacing/replanting results multitude impacts on the environment and humans as well. Environmental degradation, air pollution, and animal hunting down and forcing migrate or destruction of biodiversity are the main impacts of commercial charcoal production.

As the trees and forests burnt for charcoal production our environment would be polluted and degraded. Environmental degradation results in soil erosion, soil erosion in turn led to throw off fertility of land and production will be diminished. If the rainfall is diminished it increases the people's vulnerability to be attacked by famine and the dam water volume would be belittle and the erosion may also fill with soil which put the dam in danger of destruction.

Beyond this, the cut down of forests and trees without replanting could be dangerous to the dam. Moreover, wild animals would be migrated to other safer place. But wild animals have the right not to be harmed, and killed by humans (displaced from their natural habitat). Not only this we human beings have also the duty not kill and harm them. In addition to that, we have the responsibility to conserve and save the non-human natural creatures. People have the responsibility to manage the historical view of the mountains surrounds the river.

\section{Leopold's Argument of the "Land Ethic" as Alternative Environmental Approach}

Leopold is an American ecological and environmental scientist and he contributes a lot in preserving the natural environment. He was professor at the University of Wisconsin; he is the founder of the new model in environment ethics, the "land ethics". Leopold argues:

The extension of ethics, so far studied only by philosophers [and, Leopold's institution is clear, therefore not very revealingly studied] is actually a process in ecological evolution. An ethic, ecologically, is a limitation on freedom of action in the struggle for existence. An ethic, philosophically, is a differentiation of social from anti-social conduct. There are two definitions of one thing. The thing has its origin in the tendency of interdependent individuals or groups to evolve models of co-operation [4].

This quotation explained that, his land ethics is primarily stands for the conversation of the land by refraining harmful acts over the non-humans. For the reason that, we appeal to his theory of land ethic, to solve the environmental problems and safeguard the wild community life, particularly cut down of trees and forests for charcoal business.

The researchers strongly reject both the anthropocentric and divine (Christian) approaches toward environment in support of Leopold's argument on bio community. And we deserve his argument as alternative environmental ethical theory. His logical arguments disclosed as follows:

1. Morality or ethics concerns how we ought to act as member of the communities of which we are part.

2. Human beings are "plain members and citizens" of the biotic community (i.e. the land)

3. The biotic community can and should be regarded as amoral (or ethical) community.

4. Therefore, we ought to behave as good members of the biotic community. (from 1-3)

5. Being a good member of a community involves not disrupting, degrading, or destroying it.

6. Therefore we ought to act in ways that "preserve the integrity, stability, and beauty of the biotic community." (from 4-5) (Ibid).

According to Leopold, conservation implied to show the relationship between human thoughts and actions and their effects on the land. Herein with, he argued that, setting and applying land ethics has significant role to conserve the nature and environment. We also agreed with Leopold's argument of the two examinations of ethical approaches to wildlife/nature, the right and wrong one. What is right for him is that, preserving the integrity, stability and beauty of the bio community and the wrong one is direct converse of this.

Moreover, Leopold said wildlife does not merely belong to some specific individuals and particular groups, but all human beings. Accordingly, we recognize Leopold's argument of land ethic to respect the land, forests, trees and other wildlife.

Slootweg also stated in his work, "The Ecosystem approach", both biodiversity and human kind are inseparable entities". In this article Slootweg argued that, "in their reasoning the value of biodiversity is best guaranteed among people by means of a participatory discussion of environmental goals". Here with in support of Slootweg, we 
argues, to control the exploitation of the non-humans or biodiversity the native and local community should make public sphere and discuss about how to conserve their environment critically and later on make social agreement and convention.

\section{Concluding Remarks}

The researchers recommend the concerned body or stakeholders (governmental and non-governmental) to apply one of the dominant environment ethical theory, deontology and the classical virtue ethics to manage and control the exploitation and destruction of non-humans (wild community life). This shows the necessity of applying ethics on the issue of the relationship between human and non-human (wild life).

\subsection{Taylor's and Leopard's Perspectives}

To minimize and overcome the environmental problems, the researchers boldly recommend the concerned body to apply the perspectives of the triple natural thinkers (Taylor and Leopard) on environmental conservation, other than approaching to the anthropocentrism and divine theories.

The prominent American philosopher, Paul W. Taylor argued that the non-humans life must be recognized as 'deserving of our moral concern and consideration because they have a kind of value that belongs to them inherently' [14]. According to the view of Taylor, human beings have the duty and responsibility to conserve and respect them and not only this; the wild community life also have the right not to be harmed by human beings.

With this regard, he said that the non-human life have values,

...it is this value that makes it wrong to treat them as if they existed as mere means to human ends. It is for their sake that their good should be promoted or protected. Just as humans should be treated with respect, so should they (Ibid).

This quotation explained, attacking and harming the nonhumans is totally wrong, because they are not necessarily created for the wellbeing of human beings. Thus, he said people should respect and protect them from human created or artificial hazards. In addition to that, we recommend the stakeholders to promote functional environmental ethic to preserve the wild community life. The wild community should be perceived as 'a unified system of organized activity, the constant tendency of which is to preserve its existence by protecting and promoting its well-being' (Ibid).

Leopold also forwarded similar argument with Taylor which is good to protect and conserve the non-humans. As we have explained earlier Leopold's argument refers that, "the land ethic is as much about the attitudes, perspectives, and dispositions that people ought to have toward the land, which includes "respect for fellow members". Hence, the concerned bodies should investigate a new and decisive land ethic and apply it to secure the natural environments and the non-humans. Unless the local government of the two zones, Wolaita and Dawro zone do something safeguard of the place, the eco-system, plants, endemic trees, even the dam will be at risk.

As we have discussed on the earlier paragraphs, setting community's environmental rule is one of the apparatuses which used to conserve natural environment and prevent them from damage. The land ethics emphasizes that peoples should promote its integrity, stability, and beauty of the biotic community (Ibid). However, setting rule on itself is not complete enough, but also strappingly following and implementing on the ground.

The concerned bodies such as government and nongovernment agents should act on the conservation of the nonhumans (plants, wildlife and environment itself) from exploitation and damage.

\subsection{Other Recommended Environmental Conservation Techniques}

Thus, the researchers pointed some, but decisive environmental conservation techniques, here below:

\subsubsection{Building Botanic Gardens and Lodges}

Inspiring financiers to invest their capital to build entertainment and recreation at the area is the other principle which used to preserve the wild life. Because, they can control and protect the non-humans from danger for their mutual be benefit.

Thus, building parks and lodges at the edge of the mountain has significant role for the investors, society, government and the natural environment in general. To do so the stakeholders, mainly the government of the region and zone should invite investors and spend their capital on wildlife Park, lodges, and other refreshing enterprises. And, wild community lives remain safe from the continuous cut down and hunting by the local society; the physical environment would be attractive and beautiful. Beyond the prevention of the natural environment from exploitation and destruction, it has great role of economic and financial benefit for the investors. In addition to that, it plays a great role in making and producing fresh or clean air and environment for the society. Because if the area is protected from deforestation and cut down of trees and burning of grasses, the forest would produce oxygen by avoiding carbon.

The other expected benefit from the park and lodge is unemployment reduction and preserving the mountains from grazing and deforestation by law and give for jobless youth to produce grass for livestock and for bee honey production business. The complementary association of economy and the conservation of environment by the people would also economically benefit the society. With this regard, Adams, argued that, "economics and human well-being and biodiversity conservation are linked. According to Slootweg, the linkages were largely seen in conservation providing the revenue-generating opportunities (e.g. trade and tourism) that could contribute to local economic development in poor countries". There are a wide number of jobless citizens in Ethiopia in that area particularly. Thus, if parks and recreation or lodge are built and extended at that place (Omo- 
river area) a vast number of jobless individuals will be employed as a guardians and other work task, and they will be economically benefitted.

\subsubsection{Teaching and Training the Societies Duty and the Wild Lives Right}

The other is creating awareness about the conservation of natural environment and its relation with human. Teaching and training the societies duty is the other way of the protection of natural resource or non-humans. This includes telling the people that they have the duty even to care and conserve the non-human resources, such as, plants, trees, grasses, wildlife and other non-living resource. Since all human and non-human natural resource have the right to live and safe, the society around of Omo-river have the responsibility to refrain themselves from harming and exploiting these natural resources. They should know their duty not only refraining themselves from cutting down trees and plants but also they have to be aware of their duty of caring and preserving of these natural resources. With doing this media, churches, government, and other concerned bodies should exercise their responsibility. For instance the government should create awareness to the society know their duty towards the natural environment and stimulate the community participation on preserving them.

The local, regional and government should invite and promote for the international eco-system organizations and environmentalists and work together on the positive relation of human and the environment. The government should make serious measurement over those who broken the rule or who damage and exploit the environment for the sake of commercial and/or personal use of charcoal production.

\subsubsection{Institutionalizing Environmentalism and Environment Ethics}

Hydro-power plants, if not properly planned and managed, results in the destruction of biodiversity. In this regard the case of the Itaipu power plant is a good example for both loss of biodiversity and after proper management and control restoration of the forests and biodiversity.

Itaipu's original development resulted in the permanent loss of forests (estimated at $600 \mathrm{~km}^{2}$ ) due to the creation of the reservoir. Though it rested in the loss of biodiversity, by introducing and implanting a series important program, it was successful in declining the destruction of biodiversity and the aquatic communities [15].

Environmentalism and environmental justice has to be institutionalized and it would play a significant role to solve environmental problems. Environmentalism, both as theory and as practice, has traditionally been concerned above all with nature. Its focus is on protecting nature against the harms generated by human action [16]. And, according to J. Baird Callicott, environmental ethics, "is supposed to govern human relations with non-human natural entities" [17]. Therefore, the government promotes strong and independent environmental institution then its ultimate function would be conserving and protecting the natural environment from harm and destruction. And, they can take experience from other part of the country which are effectively applied and become successful like, Tigray region.

The institution would play a great role in both keeping our natural resources and given that prospects for people to enjoy them. Hence, the government of the region and both zones (Wolaita and Dawro) can take experience on application from other developed countries like, Switzerland, France, Denmark, America and others in institutionalizing environmentalism and environmental ethics.

\subsubsection{Tourism}

Tourism is also one of the mechanisms of protection and preservation of the wild community life, because it has direct attachment with the environment. But it must be nature (wild life's, and forests) based tourism and it will promote a significant role in preserving the bio diversity and generating economic or developmental role. The government can promote and change the area into tourism site and get mutual benefit to the government, society and the natural creatures including wild life. Communities live nearby the area will share revenue from the tourism and get economically benefited. Moreover, local communities will be employed guardian of the park. Likewise, wildlife's such as monkey, species of birds and other animals will be safely live on the park.

Accordingly, these all conservation mechanisms of natural environment (plants, trees, wildlife and the place) should be applied on the ground and the risky of the wild lives (biodiversity) in the area will necessarily be solved and secured and the community will benefit more from it. To protect the trees and stop those who are involved in charcoaling, the local and central government should act on applying the above recommended environment conversation apparatuses.

\section{References}

[1] Claudia J. Carr. River Basin Development and Human Rights in eastern Africa- a policy crossroads, 2017.

[2] http://www.ucsusa.org/resources/environmental-impactshydroelectric-power.

[3] UNEP. (2006). Africa Environment Outlook 2: Our Environment, Our Wealth. Nairobi: Progress Press Ltd, Malta.

[4] Leopold, A. (1949/1968). A Sand County Almanac, and Sketches Here and There. New York: NY: Oxford University Press.

[5] Jamieson, D. (2008). Ethics and the Environment. New York: Cambiridge University Press.

[6] James Bohman and Bill Rehg (Cambridge, MA: MIT Press, 2001), pp. 193-224

[7] S. E. (2009). The potential for species conservation in tropical secondary forests. Conservation Biology, Vol. 23, No. 6, 14061417.

[8] Miller, E. D. (1984). Questions that Matter: An Invitation to Philosophy. New York: McGraw-Hill, Inc. 
[9] Porteous, J. (1996). ENVIRONMENTAL AESTHETICS: ideas, politics and planning. USA and Canada: Taylor \& Francis e-Library, 2003.

[10] Roel Slootweg, R. R. (2010). Biodiversity in Environmental Assessment: Enhancing Ecosystem Services for Human Wellbeing. New york: Published in the United States of America by Cambridge University Press.

[11] Moutinho, P. (2012). DEFORESTATION AROUND THE WORLD. Rijeka, Croatia: InTech.

[12] Sandler, R. L. (2018). Environmental Ethics: Theory in Practice. New York: Oxford university press.

[13] Jacques P. Thiroux, K. W. (2012). Ethics: theor and pracice. New York: Nancy Roberts.
[14] Taylor, Paul, 2011 [1986]. Respect for Nature: A Theory of Environmental Ethics. Princeton: Princeton University Press.

[15] https://www.hydropower.org/sites/default/files/publicationsdocs/Better $\% 20$ Hydro $\% 20$ Compendium $\% 20$ of $\% 20$ Case $\% 20 \mathrm{~S}$ tudies\%202017.pdf

[16] Vogel, S. (2015). Thinking like a mall: environmental philosophy after the end of nature. Cambridge, Massachusetts, London, England: The MIT Press.

[17] Callicott, J. Baird. In Defense of the Land Ethic: Essays in Environmental Philosophy. Albany: SUNY Press, 1989. 